\title{
CEREMONIES AND THE CITY: THE COURT IN FOURTEENTH-CENTURY CONSTANTINOPLE
}

\author{
Ruth Macrides
}

Modern reconstructions of Constantinople and its court life after 1204 delineate a city that never recovered from the events of the Fourth Crusade. While a restoration of buildings and traditions associated with Constantinople before 1204 was undertaken by Michael VIII as the 'New Constantine' ${ }^{1}$ upon his recovery of the capital, the imperial treasury was depleted by subsequent territorial losses to the Turks and the civil wars of the 1320 s and ' 40 s. Disasters such as the plague of $1347^{2}$ contributed to the reduction in the empire's resources. Decline, it is reasonably assumed, took its toll also on the ceremonial life of the court. 'Ceremonial space'3 diminished and the content of the ceremonies became impoverished. There was a reduction in the scale of the ceremonies performed and an isolation of the court's routines. ${ }^{4}$

This picture of court life in the reconquered Constantinople, which is generally regarded as representative of the whole of the late Byzantine period from the late thirteenth century to $1453,{ }^{5}$ is based on the one surviving text from the period after 1204 that contains descriptions of

\footnotetext{
1 Alice-Mary Talbot, 'The Restoration of Constantinople under Michael VIII', Dumbarton Oaks Papers 47 (1993) pp. 243-261; Ruth Macrides, 'The New Constantine and the New Constantinople-1261?', Byzantine and Modern Greek Studies 6 (1980) pp. 13-41; eadem, 'From the Komnenoi to the Palaiologoi: Imperial Models in Decline and Exile', in: New Constantines, ed. P. Magdalino (Aldershot 1994) pp. 269-282, here at pp. 270-275. The study by V. Kidonopoulos, Bauten in Konstantinopel, 1204-1328 (Wiesbaden 1994) was not available to me.

${ }^{2}$ For a narrative of the events of the late thirteenth and early fourteenth centuries see Donald M. Nicol, The Last Centuries of Byzantium, 1261-1453 (Cambridge 1972, 1993).

${ }^{3}$ André Grabar, 'Pseudo-Codinos et les cérémonies de la cour byzantine au $\mathrm{XIV}^{\mathrm{e}}$ siècle', Art et société à Byzance sous les Paléologues (Venice 1971) pp. 195-221, here at p. 200.

4 Argued by Paul Magdalino, 'Pseudo-Kodinos' Constantinople', Studies on the History and Topography of Byzantine Constantinople (Aldershot 2007) study XII, pp. 1-14 (first publication); idem, 'Court and capital in Byzantium', in this volume.

${ }^{5}$ Nuance has not been introduced so far to modern representations of ceremonial in the 'Palaiologan period'. An exception is the careful approach of T. Kiousopoulou,

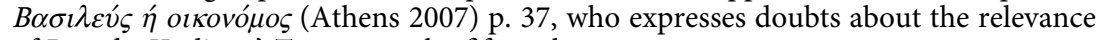
of Pseudo-Kodinos' Treatise to the fifteenth century.
} 
ceremonies, the so-called Treatise on the court titles by the anonymous author known to us as Pseudo-Kodinos. The text dates to some time in the mid-fourteenth century, to the reign of John VI Kantakouzenos, ${ }^{6}$ the emperor whose crown was made of glass paste gems and whose coronation banquet tableware was earthenware and pewter. ${ }^{7}$

The modern portrayal of a reduced and impoverished ceremonial and court life, I will argue, relies not so much on the text of PseudoKodinos itself, as on expectations and preconceptions created by the tenth-century Book of Ceremonies. The latter is the standard against which the Treatise is measured, explicitly or implicitly. The contrast in the two works is indeed great. The De cerimoniis is a large text with a reputation that goes beyond the boundaries of the academic community; the Treatise is a slim work, barely known even to Byzantinists. The Book of Ceremonies has an ascribed author, Constantine VII, an emperor, and a learned one at that, and an approximate date, 957959. ${ }^{8}$ It has a preface or, rather, two, one for each book of the work. In these prooimia, Constantine VII lays great emphasis on taxis, 'order', the principle behind the work. The word appears six times in the first preface and four times in the second, together with ataxia, 'disorder', and eutaxia, 'good order'. The much-quoted prefaces make clear the central importance of maintaining good order in the palace, both for the subjects of the emperor and for foreigners. ${ }^{9}$

${ }^{6}$ The text, with facing-page French translation, notes and introduction was published by Jean Verpeaux, Traité des offices (Paris 1966). For the date, see Verpeaux, Traité, pp. 25-40. John VI is the last emperor mentioned by name in the text: ed. Verpeaux, 135.6-136.1; 147.17-148.3. A new study of the Treatise, with Greek text and facing English translation is forthcoming: Pseudo-Kodinos, The Constantinopolitan court offices and ceremonies, ed. and trans., with commentary, R. Macrides, J. Munitiz, D. Angelov (Farnham 2013).

${ }^{7}$ Nikephoros Gregoras, Byzantina Historia II, Ludwig Schopen, ed. (Bonn 1830) 788.15-789.8; Nicol, Last Centuries, p. 215. The glass paste crown is not mentioned again after Kantakouzenos' coronation.

${ }_{8}$ Michael McCormick, 'De ceremoniis', The Oxford Dictionary of Byzantium, A.P. Kazhdan, ed., 3 vols. (New York; Oxford 1991) vol. 1, pp. 595-597, here at p. 595. For Constantine as the author of the prefaces and instigator of the compilation which we call the Book of Ceremonies and which was continued after his death, see Ihor Ševčenko, 'Re-reading Constantine Porphyrogenitus', in: Byzantine Diplomacy, Jonathan Shepard and Simon Franklin, eds. (Aldershot 1992) pp. 167-196; Michael Featherstone, 'Further remarks on the De cerimoniis', Byzantinische Zeitschrift 97, 1 (2004) pp. 113-121.

${ }_{9}$ The complete work was edited by Reiske in one volume: Johann Jacob Reiske, ed., Constantini Porphyrogeneti De Cerimoniis aulae byzantinae I (Bonn 1829) pp. $3-5 ; 516-517$. Book I has been published with French translation and commentary 
The Treatise, in contrast, has no known author, no known date, no preface, nor any reference to the circumstances of its writing or to the significance of ceremonial. These aspects of the text contribute to its marginalisation. Because of the above mentioned factors, it lacks in the eyes of its readers a status as authoritative as the Book of Ceremonies; its date also contributes to this assessment: in the fourteenth century the empire was a shadow of its former self, while in the tenth, the empire was powerful and large.

Yet, before conclusions can be drawn about Byzantine ceremonial in the fourteenth century, it is important to understand the nature of the books that describe Byzantine ceremonies. The Book of Ceremonies appears to be a record of court ceremonial procedures 'whose accuracy is guaranteed by its authorship'. ${ }^{10}$ But how many of the ceremonies recorded in it were regularly performed? To what extent can it be a guide to the ceremonial life of the contemporary court? If the purpose of the tenth-century author-compiler was to put together a collection for the use of future masters of ceremony, to make accessible a wide range of protocols, then what we have in the Book of Ceremonies is a guide to the tenth century's relationship to the past. ${ }^{11}$

The Treatise on the court titles, as its editor, Jean Verpeaux, named it, differs from the Book of Ceremonies in a number of ways. First, in its content. It provides a list of titles and the functions attached to them, but also includes a description of the clothing of each title-holder, the hats worn and staffs carried by each. In addition, the anonymous author gives an account of the ceremonial for the major feast days, the Christmas and Easter cycles, and other feasts, coronations and promotions of high dignitaries and the installation of the patriarch. Other chapters deal with the clothes worn by an emperor in mourning, the reception of a foreign imperial bride-to-be in Constantinople, and the duties of the megas domestikos in the army.

From this list of contents one can see immediately that PseudoKodinos' work is like no other surviving book on Byzantine ceremony. In its combination of hierarchy and ceremony it is closer to the late

by Albert Vogt, Le livre des cérémonies, 2 vols. (Paris 1967). References here will be to the Reiske edition.

${ }^{10}$ Averil Cameron, 'The construction of court ritual: The Book of Ceremonies', in: Rituals of Royalty, David Cannadine and Simon Price, eds. (Cambridge 1987) pp. 106-136, here at p. 106.

${ }^{11}$ Cameron, 'The construction of court ritual', p. 119. 
ninth-century book on banquets, the Kletorologion by Philotheos, ${ }^{12}$ than to the Book of Ceremonies. But in its detailed delineation of clothing and insignia, it goes far beyond Philotheos and Constantine VII.

Furthermore, although the Treatise has no known author, its anonymous author has left his mark on the text throughout, in the most direct manner, through his interventions-sometimes in the first person, ${ }^{13}$ sometimes in the third. Like Philotheos and Constantine VII or a later redactor ${ }^{14}$ of the Book of Ceremonies, the author makes didactic comments: 'One should know that'; 'This too should be known'. ${ }^{15}$ But Pseudo-Kodinos goes beyond them by uniting the various parts of the Treatise with cross-references: 'As mentioned above'; 'The reason will be given afterwards'; 'One must return again to the point from which we started'. ${ }^{16} \mathrm{He}$ introduces excurses in a direct manner by pointing out that they are notes on a specific point. ${ }^{17} \mathrm{He}$ rounds off a section by summarising and pointing forward to the next. ${ }^{18}$ Among 'authors' of ceremonial books, Pseudo-Kodinos is the most interventionist, showing his editorial work in a direct manner and establishing an internal cohesion, as well as a direct connection with his readers. If his text is a compilation, made up of texts not originally composed by him, ${ }^{19}$ he manages to create the impression of a composition that is a coherent whole.

By contrast, the Book of Ceremonies shows clearly the disparateness and separateness of the sources which make up its composition, for Constantine VII, or a later editor of the work, does not attempt to

${ }^{12}$ Nicolas Oikonomides, Les listes de préséance Byzantine des IXe et $X^{e}$ siècles (Paris 1972).

${ }^{13}$ Ed. Verpeaux, 148.16-17; 173.6-19.

${ }^{14}$ Jeffrey M. Featherstone, ' $\Delta \mathrm{I}$ ' EN $\Delta$ EIEIN. Display in court ceremonial (De cerimoniis II, 15)', in: The Material and the Ideal: essays in medieval art and archaeology in honour of Jean-Michel Spieser, Anthony Cutler and Arietta Papaconstantinou, eds. (Leiden 2007) pp. 75-112, here at pp. 77-79; cf. A. Moffatt, 'The Master of Ceremonies' bottom drawer. The unfinished state of the De ceremoniis of Constantine Porphyrogennetos', Byzantinoslavica 56 (1995) pp. 377-388, here at p. 381.

${ }_{15}$ Ed. Verpeaux, 168.28, 191.22, 199.3, 223.22, 226.22, 230.23, 240.5, 272.21, 273.1, 274.28, 281.6, 281.24, 286.2, 287.22.

${ }_{16}$ Ed. Verpeaux, 167.7-11, 200.11-13, 257.26, 272.4, 272.5, 287.7.

17 Ed. Verpeaux, 199.3-200.13, 204.24-206.8, 218.29-219.21, 222.14-223.21, 235.12237.5, 259.1-8, 270.1-12, 273.1-18, 287.22-29.

${ }^{18}$ Ed. Verpeaux, 207.9-10.

19 Verpeaux had not identified fully the compilatory nature of the work, evident in several sections. The list of titles is based on a ready-made list of the early fourteenth century; the coronation section is certainly taken from another source. For the latter, see Verpeaux, Traité, pp. 31-34. 
create a unified whole from the different documents of differing dates. Thus, the work has been characterised as 'more a dossier than a finished work'. ${ }^{20}$ Sources from the fifth to tenth centuries are found next to passages that date to a time after Constantine VII's death. Prescriptive passages can be found next to old material that has been included simply to make it accessible. ${ }^{21}$

Another characteristic of the Treatise is its overwhelming attention to detail. The author-compiler lavishes most attention on details that have to do with the hierarchical order of the court officials, their insignia of office, especially their clothing and their batons, but above all their headgear. ${ }^{22}$ From both visual and textual records it appears that hats had become an item of court attire from the eleventh century on. ${ }^{23}$ However, this author-compiler's account is the only systematic description of headgear for the entire Byzantine period and only his description makes it possible to reconstruct to some extent the appearance of the court when it met twice daily also on feast days. No surviving image provides this picture. ${ }^{24}$

Two hats are described by the author, the skiadion, the everyday hat which has not been identified securely with any hat from the visual record, and the skaranikon, the feast day hat which is better documented. It is on the latter that the author concentrates and there are many surviving portraits of officials wearing these hats. ${ }^{25}$

The author divides the court officials into two groups, the goldskaranikon wearers and the red-skaranikon wearers. ${ }^{26}$ However, the

${ }^{20}$ McCormick, 'De ceremoniis', p. 595.

${ }^{21}$ For an analysis of the dates of the documents in the work, see the groundbreaking study by J.B. Bury, 'The Ceremonial Book of Constantine Porphyrogennetos', English Historical Review 86 (April 1907) pp. 209-227, and idem, English Historical Review 87 (July 1907) pp. 417-439; Mc Cormick, 'De ceremoniis', pp. 596-597. For the unfinished state of the work and the 'scissors and paste' nature of the compilation' see Moffatt, 'The Master of Ceremonies' bottom drawer', pp. 377-388.

${ }^{22}$ Ed. Verpeaux, 141-166.

${ }^{23}$ Nancy Sevčenko, 'Headgear', Oxford Dictionary of Byzantium, ed. A.P. Kazhdan, 3 vols. (Oxford; New York 1991), vol. 2, p. 904; Maria G. Parani, Reconstructing the Reality of Images (Leiden 2003) p. 67.

${ }^{24}$ The only image of the court from the later Byzantine period is the manuscript illumination of John VI Kantakouzenos presiding over the council of 1351: Par. gr. 1242, f. 5 v. See Parani, Reconstructing the Reality of Images, pl. 24.

${ }^{25}$ See, for example, the images from the Lincoln College Typikon (ms. gr. 35) and Par. gr. 2144, both fourteenth century, reproduced in Parani, Reconstructing the Reality of Images, pl. 67, 68.

${ }^{26}$ Ed. Verpeaux, 211.8-10; 216.5-8; 219.27-30. 
differences in the appearance of the skaranika are far greater than this division implies. The distinctions have to do with fabric, colour, type of decoration and material of decoration. The author gives the names of the title holders who belong to each group. The hats described as 'gold' skaranika begin with the brilliant imperial colour of red and become paler, from apricot to white and yellow, the latter two being colours that the emperor wears when he is in mourning. These court title holders, it seems, wear silk hats of red, apricot, white or yellow, with threads of gold woven into them. The hats in this group are also described as syrmateina, perhaps an indication that the skaranika were embroidered with gold-wire thread. ${ }^{27}$

The quality of the fabric-silk-and the decoration-gold threaddistinguishes the first group, the highest members of the court, from the second. The second group, the wearers of 'red' skaranika, officials lower down in the hierarchy, ${ }^{28}$ are sharply distinguished from group one by the fabric of their hats, the design and colour. Their skaranika are solid red, made of a fabric with a nap, ${ }^{29}$ such as velvet or felt. These skaranika have no gold but rather a tassel. All the officials in this group are coiffed in identical red-tasselled hats. There are no variations. There is no gradation within this group and it is immediately recognizable and distinct from the first.

Within the first group, however, a further internal hierarchical distinction is made. These are the hats that are gold with red, apricot, white and yellow. They all bear the image of the emperor, on the front and the back. It is the portrait of the emperor on the hat that makes the skaranikon so easily identifiable in manuscript illuminations and elsewhere. The emperor's image was an additional element that contributed to the ranking based on colour. The material and technique used to create the emperor's image distinguished smaller groups within the larger one. The gold-red hats at the top of the hierarchy had the emperor's image engraved or beaten onto a metal plaque attached to the front and the back. The gold-apricot and gold-white hats had the

27 Ed. Verpeaux, 142 n. 3.

28 Ed. Verpeaux, 211.8-20; 163.7-9.

${ }^{29}$ For the material of this hat, chasdeon, see Maria Mavroudi, A Byzantine Book on Dream Interpretation (Leiden 2002) pp. 65-66 n. 14; p. 471. 
image painted on glass to imitate enamel. ${ }^{30}$ Finally, the gold-yellow hats had the image of the emperor embroidered in gold-wire thread.

The iconography of the imperial image varied also, depending on the medium. The metal plaques-silver or silver gilt-depicted the emperor standing on one side and enthroned on the other. The painted glass and the embroidered images showed the emperor enthroned on one side and on horseback on the other.

The distinctions between the two main groups, the 'gold' and 'red' skaranika, therefore, were multiple, based on differing fabric (silk or velvet), colour (gold and another colour or red alone), decoration (portrait of the emperor or tassel), and medium of decoration (metal, imitation enamel, embroidery or cloth tassel). Just as colour marked the higher court officials from the lower, so too did material used and medium employed. The observer would know at once to which rank the official belonged.

Likewise the staffs, or dikanikia, held by most of the title-holders show enormous variety. The highest title-holders carried gold and silver batons; those below in rank had batons of wood, painted gold in combination with red, black or blue. The knobs could be incised or not, while the segments between the knobs were decorated in different ways. $^{31}$

The same attention to detail is evident in other sections of the Treatise, notably in matters of horse etiquette. Pseudo-Kodinos refers, in various parts of his work, to places in the courtyard of the palace that are specifically for mounting and dismounting. ${ }^{32}$ Only the highest dignitaries, the despot, the sebastokrator and the caesar can enter and leave the courtyard on horseback. But these three dignitaries must dismount at specifically designated areas of the courtyard.

As with dress and insignia, Pseudo-Kodinos' detailed specifications of the space in the palace courtyard have a hierarchical significance.

\footnotetext{
${ }^{30} \mathrm{~W}$. Woodfin, 'The materials make the man: hierarchies of media and hierarchies of offices in the Palaiologan court', unpublished paper read at the workshop on PseudoKodinos, Centre for Byzantine, Ottoman and Modern Greek Studies, University of Birmingham, 20-21 May 2005. Woodfin identifies the technique used to create the image, described by Pseudo-Kodinos as being 'under glass' as 'verre eglomisé', painting on the reverse side of glass. On the latter see Dillian Gordon, 'A Sienese verre eglomisé and its setting', Burlington Magazine 123 (1981) pp. 148-153.

${ }^{31}$ Ed. Verpeaux, 141-166.

32 Ed. Verpeaux, 145.13-15 (the despot), 148.14-21 (the sebastokrator), 149.11-14 (the caesar), 281.6-9 (the patriarch).
} 
Similarly, hierarchical principles are at the core of the protocol of the 'kiss' given to the emperor on Easter Sunday. 'All the title-holders enter', reports Pseudo-Kodinos,

each one down to the humblest, and kiss, first the right foot of the emperor, then his right hand and, after this, his right cheek. If, at that moment, the podestà of the Genoese in Galata also happens to be at the place where the emperor is, he too enters and with his companions kisses the emperor in the manner of the title-holders.... However, the Venetians come neither to the 'many years' acclamations nor to the kiss. ${ }^{33}$

In this passage the author gives a short guide to the diplomatic gestures of the representatives of the Latins in Constantinople. The Genoese are treated differently from the Venetians. The author explains the origins of the differentiation made, ${ }^{34}$ as he does the origins of peoples, objects, articles of clothing, customs and practices. ${ }^{35}$

By providing explanations of origins Pseudo-Kodinos relates to the past and shows awareness of continuity and discontinuity. ${ }^{36}$ But there are also many cases where he declares his ignorance. He expresses the latter with the characteristic phrase, 'It is unknown', expressed in Greek in a variety of ways. ${ }^{37} \mathrm{~A}$ considerable range of subjects falls into the category of the unknown. It is Pseudo-Kodinos' curiosity about all kinds of practices that leads him to pose the question out loud, even if he has no answer. Why are trumpets not sounded when the emperor rides out after lunch to receive his subjects' petitions? Why do the kraktai, the singers, precede the emperor to the palace after the coronation, holding spears decorated with red and white silk streamers? ${ }^{38}$

33 Ed. Verpeaux, 234.22-235.13.

34 Ed. Verpeaux, 235.14-237.5. For a discussion of the passage see Ruth Macrides, " "The reason is not known." Remembering and recording the past. Pseudo-Kodinos as a historian', L'écriture de la mémoire. La littérarité de l'historiographie, Paolo Odorico, Panagiotis Agapitos, Martin Hinterberger, ed. (Paris 2006) pp. 317-330, here at pp. 323-325.

35 Peoples: the Vardariots (182.6-10); objects: pilatikia (205.21-206.1), dragon banner (206.5-22); clothing: turban, skaranikon, epilourikon, caftan (206.5-22), granatza (218.29-219.12); customs: emperor's horse decoration (270.1-10); emperor's gifts to clerics (237.29-238.4); practices: pinkernes' cup (211.27-212.3); archdeacon of church (222.14-223.21). On the clothing, see Maria G. Parani, 'Cultural identity and dress: the case of late Byzantine ceremonial costume', Jahrbuch der Österreichischen Byzantinistik 57 (2007) pp. 95-134.

36 Macrides, "“The reason is not known.”', pp. 321-330.

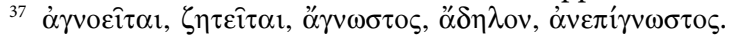

38 Ed. Verpeaux, 173.1-15; 263.4-20. 
From these examples it can be seen that Pseudo-Kodinos' Treatise is marked by its detailed description of dress and insignia and the author's curiosity about origins of practices and of objects which he expresses in a direct and open manner. ${ }^{39}$ These two aspects of his work set him apart from Philotheos and Constantine VII. In his study of the Treatise, André Grabar remarked that the Book of Ceremonies does not have one-tenth the detail of the Treatise. ${ }^{40}$ One could add that the Book of Ceremonies does not reveal its author or redactor, as does the Treatise.

The Treatise has another characteristic that sets it apart from the Book of Ceremonies: it is organised and orderly. Although the Treatise is also a compilation, the compiler has made efforts to unite not only the various sections of the work into one coherent whole but also to bring together the information within each section that derives from different sources. The impression is created of a single work written by one author. The exact opposite is the case with the Book of Ceremonies which was ostensibly compiled to reintroduce 'order' into the court ceremonies but actually achieves disorder.

As is apparent from what has been said so far, each of the ceremonial books that have survived is distinctive and unique. It follows, therefore, that there is no such thing as a model book of ceremonies. We have no handbook outlining the constituent parts of a ceremonial book, no equivalent of a Menander Rhetor for those who want to compile a ceremony book. Yet, I would argue, we have come to think of the Book of Ceremonies as the prototype and to interpret the Treatise accordingly. Thus, the Treatise appears to be the site of loss and decline, both with regard to the topography of the ceremonies and their content. Gone are the face-to-face encounters of the emperor with the people at the Hippodrome meetings, gone are the processions to churches all over the city, gone are the labyrinthine processions within the palace, winding through numerous named rooms. According to this view, the fourteenth-century ceremonial book shows a limited number of ceremonies taking place in a small number of palace rooms. Court and emperor are rarely seen by the people of the city. Ceremonies have retreated to the confined space of a few rooms in a

${ }^{39}$ Macrides, “"The reason is not known.”, pp. 320-328.

${ }^{40}$ Grabar, 'Pseudo-Codinos et les cérémonies de la cour byzantine au XIV ${ }^{\mathrm{e}}$ siècle', p. 203. 
fortified palace building, ${ }^{41}$ a single structure rather than the sprawling complex of late antiquity and of the Book of Ceremonies.

That palace was the Blachernai in the northwest corner of the city. ${ }^{42}$ The former heart of the capital in the southeast, with the Great Palace and the neighbouring Hagia Sophia, hardly appears in the Treatise. On only one occasion is the Great Palace mentioned explicitly: the emperor sleeps there the night before his coronation and has a meal there the evening of his coronation. ${ }^{43}$ Hagia Sophia is the venue for only a small number of feast days. ${ }^{44}$ Thus, from the Treatise we have a view of Constantinople from a side of the city diametrically opposite that which the Book of Ceremonies presents..$^{45}$

The view of the city from the northwest corner is one that the emperor and the court had, with increasing frequency, in the course of the twelfth century. The Blachernai became the preferred imperial residence from the end of that century ${ }^{46}$ and continued to be during the Latin occupation ${ }^{47}$ and beyond. When Michael VIII recovered Constantinople in 1261, he occupied the Great Palace while the Blachernai was being cleaned of the Latins' soot and grease..$^{48}$ In the reigns

${ }^{41}$ Grabar, 'Pseudo-Codinos et les cérémonies de la cour byzantine au XIV e siècle', pp. 200-201; Magdalino, 'Pseudo-Kodinos' Constantinople', pp. 1-3; idem, 'Court and Capital in Byzantium' in this volume pp. 141-143.

${ }_{42}$ Although Pseudo-Kodinos never mentions the Blachernai by name as the site of the ceremonies, it can be identified through internal references.

${ }^{43}$ Ed. Verpeaux, 252.2-7, 271.1-3.

${ }^{44}$ Ed. Verpeaux, 252.12-15 (coronation); 237.21-23 (Easter Sunday vespers); 242.22-243.1 (13 November: feast of John Chrysostom); 245.11-13 (15 August: Dormition); 246.7-9 (Sunday of Orthodoxy).

${ }_{45}$ Magdalino, 'Pseudo-Kodinos' Constantinople', p. 1.

46 Paul Magdalino, 'Manuel Komnenos and the Great Palace', Byzantine and Modern Greek Studies 4 (1978) pp. 101-114, here at pp. 110-113; repr. in Paul Magdalino, Tradition and Transformation in Medieval Byzantium (Aldershot 1991) study V. Magdalino shows that, contrary to received opinion, Manuel I Komnenos (11431180) made considerable use of the Great Palace until the end of his reign, having added to its buildings.

47 The Byzantine sources refer to Baldwin II, in particular, in association with the Blachernai: George Pachymeres, Relations historiques, A. Failler, ed., 5 vols. (Paris 1984-2000) vol. 1, pp. 199.12-17; Nikephoros Gregoras, L. Schopen, ed., 3 vols. (Bonn 1829-1855) vol. 1, pp. 304-305, esp. pp. 304.24-305.6.

${ }^{48}$ Pachymeres, Relations historiques, vol. 1, pp. 219.2-10. It seems, however, that Michael VIII was able to occupy the Blachernai early in his reign, while Arsenios was still patriarch (1260-1264): Pachymeres, Relations historiques, vol. 2, pp. 341.23-28. 
of his successors the Great Palace is occasionally mentioned as the venue for an event but it is the Blachernai that is occupied. ${ }^{49}$

However, although it was occupied continuously in the Palaiologan period, evidence for the Blachernai palace is meagre. Robert of Clari, writing shortly after the Fourth Crusade, is the only author to give a general impression of the palace which he describes as consisting of 'two hundred rooms or three hundred' 'all connected with each other', and twenty chapels. ${ }^{50}$ Occasional references to the palace and its rooms in Byzantine narrative sources are insufficient to attempt any kind of reconstruction. In contrast, the Great Palace's layout can be pieced together to some degree using the Book of Ceremonies and narrative sources. ${ }^{51}$ The Book of Ceremonies gives the names of the rooms and spaces in which ceremonies were performed and through which the title-holders moved in their processions. Indeed, in many descriptions of actual ceremonies that took place, as well as in the prescriptive material, the author appears to put more emphasis on the locations than on any other aspect of the ceremonial. ${ }^{52}$

Nothing could be more different than the approach of PseudoKodinos who makes reference to only a small number of rooms, none by name. In the Treatise three rooms or areas are mentioned: the triklinos $^{53}$ which acts as a reception room and dining room, the kellion or kellia ${ }^{54}$ the emperor's private apartments, and the ekklesia, the chapel or palace church. ${ }^{55}$ The latter two are connected to the triklinos or adjacent to it. In addition, there is an external elevated gallery, the peripatos, ${ }^{56}$ which connects the triklinos to the palace church. In the courtyard, in addition to the peripatos, there is a chapel dedicated

49 For occasional use of the Great Palace, see Pachymeres, Relations historiques, vol. 3, pp. 163.9-14 (1289: the Justinianeion); vol. 3, pp. 221.18-21 (1294: the Manuelites), vol. 4, pp. 401.7-12 (1303: the peripatos outside the Chrysotriklinos).

50 Robert of Clari, La conquête de Constantinople, Philippe Lauer, ed. (Paris 1924) $\$ 83$; Peter Noble, ed. (Edinburgh 2005) \$83, pp. 102-3.

${ }^{51}$ Jeffrey M. Featherstone, 'The Great Palace as reflected in the De Cerimoniis', in F.A. Bauer, ed., Visualisierungen von Herrschaft. Frühmittelalterliche ResidenzenGestalt und Funktion, Byzas 5 (Istanbul 2006) pp. 47-61; Magdalino, 'Pseudo-Kodinos' Constantinople', p. 3.

${ }^{52}$ Ed. Reiske, 75-112. This certainly applies to the protocols from the embassy of Olga of the Rus in the reign of Constantine VII. On these see Featherstone, ' $\Delta \mathrm{I}$ ' EN $\Delta$ EIछIN', pp. 75-112.

${ }^{53}$ Ed. Verpeaux, 174.18, 176.21,180.3, etc.

54 Ed. Verpeaux, 180.2, 189.9, 194.9, 212.5, etc.

55 Ed. Verpeaux, 195.9-10, 197.5, etc.

56 Ed. Verpeaux, 224.6, 17; 225.7, 28; 226.6. 
to the Mother of God 'the Victory Bringer' with a mural icon of St George facing the courtyard ${ }^{57}$ and also a tall structure, the prokypsis. ${ }^{58}$ The gate by which one enters the courtyard, Ta Hypsela ${ }^{59}$ is also mentioned. Within the courtyard also, a couple of places are specified as the areas for dismounting, the pezeuma and the tetrastylon. ${ }^{60}$

As the above summary of Pseudo-Kodinos' references to spaces shows, the greatest number of specifications is for the courtyard of the palace. It is only with respect to this area that we find references to named structures or objects: the chapel of the Mother of God 'the Victory Bringer', the icon of St George, Ta Hypsela, the pezeuma, the tetrastylon and the prokypsis. Within the palace, by contrast, rooms are known only by their generic names: the hall (triklinos), the private apartment (kellion), the chapel (ekklesia).

Apart from the prokypsis platform in the courtyard, mentioned by Nikephoros Gregoras also and attributed by Nikephoros Kallistos Xanthopoulos to Andronikos $\mathrm{II},{ }^{61}$ and the chapel of the Mother of God 'the Victory Bringer' with its mural icon of St George, known also from Gregoras, ${ }^{62}$ it is not possible to locate the structures mentioned by Pseudo-Kodinos, nor to identify them securely with buildings known from other sources. ${ }^{63}$ The triklinos of Pseudo-Kodinos' ceremonies may have been the Alexiakos triklinos, built by Alexios I Komnenos in the late eleventh century ${ }^{64}$ It is cited three times as the venue for assemblies of churchmen presided over by the emperors Michael VIII, Andronikos II, and John VI Kantakouzenos ${ }^{65}$ The chapel of the palace can perhaps be identified with that of St Demetrios, mentioned by Kantakouzenos.$^{66}$ Otherwise, the late Byzantine narrative accounts refer to various residences, part of the Blachernai palace or distinct

57 Ed. Verpeaux, 227.10-15, 228.1.

58 Ed. Verpeaux, 197.8, 25-26.

59 Verpeaux, 243.23, 244.6.

${ }^{60}$ Verpeaux, 168.21; 244.8; 148.16, 20-21.

${ }^{61}$ Gregoras II, 616-617; Xanthopoulos, Migne, Patrologia Graeca 145, 585-588, here at 585 B; translation of Xanthopoulos passage in Magdalino, 'Pseudo-Kodinos' Constantinople', pp. 13-14, here at p. 13.

${ }^{62}$ Gregoras, I, 304.8-12.

${ }^{63}$ Magdalino, 'Pseudo-Kodinos' Constantinople', p. 3.

${ }^{64}$ For another view see Magdalino, 'Pseudo-Kodinos' Constantinople', p. 4.

65 Pachymeres, Relations historiques, vol. 2, pp. 339.23-341.20; vol. 3, pp. 209.25211.7; Gregoras II, 898-899. The Par. gr. 1242, fol. 5v shows John VI presiding over the synod of 1351 .

${ }^{66}$ John Kantakouzenos, ed. L. Schopen, 3 vols. (Bonn 1828-1832) II, 47.15-17; 66.10-12. 
from it: the residence (oikia) in the courtyard of the palace where John Kantakouzenos' mother was kept imprisoned and which was built by Andronikos II ${ }^{67}$ and the 'house of the Porphyrogennetos' ${ }^{68}$

These identifications are tentative and the references to palace buildings do not amount to much. The conclusion has therefore been drawn that in the late period ceremonies took place in a restricted space, in a ruin of a palace hardly worthy of the name. This impression is reinforced by the later, fifteenth-century accounts of foreign visitors to Constantinople, Clavijo and Tafur, Spanish travellers to the city in the reigns of Manuel II (1391-1425) and John VIII Palaiologos (1425-1448) who have left reports of their receptions in the palace. ${ }^{69}$ Clavijo and his party crossed over from Pera and found horses and officers to take them up to the palace. There the emperor received them graciously in his 'private chamber', seated on a raised dais, carpeted with small rugs. On one was spread a skin. 'With the emperor at our audience had been present the Empress, his wife, with three young princes his sons... ${ }^{70}$ Is this private chamber the kellion of PseudoKodinos' account? The audience is familial and intimate.

Tafur was in Constantinople at the time of John VIII's departure for the church council of Ferrara-Florence in 1437. He describes the impression that the palace made on him:

The Emperor's Palace must have been very magnificent, but now it is in such state that both it and the city show well the evils which the people have suffered and still endure... Inside, the house is badly kept, except certain parts where the Emperor, the Empress, and attendants can live, although cramped for space. ${ }^{71}$

${ }^{67}$ Kantakouzenos II, 164.20-165.2; Gregoras II, 616-617; Xanthopoulos, Patrologia Graeca 145, 585B; Magdalino, 'Pseudo-Kodinos' Constantinople', pp. 5, 13-14.

${ }^{68}$ Kantakouzenos I, 305.21; III, 290.15. The 'house of the Porphyrogennetos' is usually identified with the three-storey palace whose remains can be seen at the north termination of the Theodosian land walls. See Cyril Mango, 'Tekfur Sarayi', The Oxford Dictionary of Byzantium, A.P. Kazhdan, ed., 3 vols. (New York; Oxford 1991) vol. 3, pp. 2021-2022. Neslihan Asutay-Effenberger, Die Landmauer von Konstantinopel-Istanbul (Berlin; New York 2007) pp. 134-42 argues that the Tekfur Sarayi was the palace occupied in the last years of the empire.

${ }^{69}$ M. Angold, 'The decline of Byzantium seen through the eyes of western travellers', in: Travel in the Byzantine World, Ruth Macrides, ed. (Aldershot 2002) pp. 213-232, here at pp. 220-221, 223-225.

${ }_{70}$ Embajada a Tamorlan, F. López Estrada, ed. (Madrid 1943) p. 34; Clavijo, Embassy to Tamerlane 1403-1406, G. Le Strange, trans. (London 1928) p. 61.

${ }^{71}$ Pero Tafur, Travels and Adventures 1435-1439, M. Letts, trans. and ed. (London 1926) p. 145. 
Tafur also was given audience before the emperor: 'I then entered the Palace, and came to a hall where I found him [the emperor] seated on a tribune, with a lion's skin spread under his feet'. ${ }^{72}$

In the two accounts of Clavijo and Tafur one is struck by the intimate nature of the reception-the emperor and his family-known also from some tenth-century receptions. ${ }^{73}$

Does Tafur's description of the palace-'Inside the house is badly kept, except certain parts where the emperor, the empress and attendants can live, although cramped for space'-conform to the palace in Pseudo-Kodinos' time? The Spanish traveller was in Constantinople approximately 100 years later than Pseudo-Kodinos, close to the Ottoman conquest. By then the palace might indeed have been reduced to a ruinous state. But, it is not even certain that the palace Tafur describes is the Blachernai, for his description comes in the part of his account that is a general description of the city; it follows his mention of the Hippodrome which adjoined the Great Palace. ${ }^{74}$

A further obstacle to uncovering the nature of Pseudo-Kodinos' palace is his lack of a protocol for the reception of foreign visitors to the capital. As it is impossible to conclude from the absence of such a protocol that foreigners were not given audience, we must assume that Pseudo-Kodinos omitted the protocol for another reason. Again we return to the differences in the nature of the two ceremonial books.

Receptions of ambassadors are not the only ceremonies that do not appear in Pseudo-Kodinos' work. Descriptions of processions inside the palace are likewise missing. In fact, for Pseudo-Kodinos, the word $\dot{\alpha} \pi \dot{\varepsilon} \rho \chi \varepsilon \tau \alpha 1-$ 'he goes', ${ }^{75}$ suffices for any description of movement. On the occasion when the emperor is said to leave the palace to accompany the icon of the Hodegetria to the boundaries of the palace, to the gate called Ta Hypsela, we are not told what route he took or what spaces or rooms he passed through to arrive at his destination. ${ }^{76}$ No processions are recounted in detail and, therefore, no (other) rooms

${ }^{72}$ Tafur, Travels and Adventures, p. 117.

${ }^{73}$ E.g. the receptions of Olga of Kiev: see Featherstone, ' $\Delta \mathrm{I}$ ' EN $\Delta$ EIEIN', 107-108, $109,111,112$.

${ }_{74}$ Tafur, Travels and Adventures, pp. 141-146. Tafur's palace description (p. 145) comes much later than his mention of his reception by the emperor (p. 117). G.P. Majeska, Russian Travelers to Constantinople in the Fourteenth and Fifteenth Centuries (Washington, D.C. 1984) p. 244, assumes that Tafur refers to the Great Palace.

${ }^{75}$ E.g., ed. Verpeaux, 242.10, 14, 23; 243.8, 10, 14; 244.13.

${ }^{76}$ Ed. Verpeaux, 231.6-12. 
are mentioned. Yet we know that processions did take place for, the 'daily procession' of the title-holders that occurred twice a day, as in the time of the Book of Ceremonies, is mentioned more than once. ${ }^{77}$ Yet, unlike the earlier ceremonial text, the fourteenth-century one does not relate how the title-holders reached the reception room.

The lack of description of internal processions is paralleled by an equally uninformative account of movement outside the palace. The emperor celebrates certain feast days in churches and monasteries scattered throughout the city. ${ }^{78}$ The closest venues are the Blachernai church and the Petra monastery, while the Peribleptos and St Demetrios, on the Sea of Marmara, and the Mangana and St Lazaros, on the Bosphoros, are the furthest from the palace. ${ }^{79}$ When the emperor leaves the palace to attend services in these places Pseudo-Kodinos does not relate how the emperor travelled, except in two cases, for the celebrations in the Blachernai church on his doorstep, and in the Petra monastery, not far away. In these instances, he states: 'The Varangians accompany the emperor. They always accompany him when he rides on horseback' ${ }^{80}$ Are we therefore to conclude that the emperor went by sea on the other occasions ${ }^{281}$ Rather, it seems that Pseudo-Kodinos specifies the Varangian escort in these cases simply because it is only then that the Varangians accompany the emperor all the way to the church or monastery. In the other cases, they go as far as the outer gate of the palace and wait there for the emperor to return. ${ }^{82}$ Thus, although it can be inferred that the emperor went on horseback to the other venues, we are not told what kind of an escort he had.

It would appear from these examples that, although Pseudo-Kodinos provides detail in relation to dress and other aspects of court life, ${ }^{83}$ description of movement does not feature much in his work, in great contrast to the Book of Ceremonies which could be said to be mainly about processions. ${ }^{84}$ Instead, it is the static tableau on which

77 Reiske, 518-522; ed. Verpeaux, 191.22-23; 212.15-17.

${ }_{78}$ Ed. Verpeaux, 242-247.

${ }^{79}$ Magdalino, 'Pseudo-Kodinos' Constantinople', pp. 6-11.

${ }^{80}$ Ed. Verpeaux, 243.17-21.

${ }^{81}$ Albrecht Berger, 'Imperial and ecclesiastical processions in Constantinople', in: Byzantine Constantinople, Nevra Necipoğlu, ed. (Leiden 2001) pp. 73-85, here at pp. 83-85.

${ }^{82}$ Ed. Verpeaux, 243.20-244.8; 244.16-245.2.

${ }^{83}$ See above, pp. 221-224.

${ }^{84}$ Cameron, 'The construction of court ritual', pp. 112, 114; Berger, 'Imperial and ecclesiastical processions', pp. 73-85, here at p. 77; McCormick, ODB I, p. 596. 
Pseudo-Kodinos lavishes most time and space. His account of the prokypsis ceremony that took place on Christmas Eve and Epiphany constitutes the longest single description of a ceremony in his work. ${ }^{85}$ The emperor, elevated on a tall structure in the courtyard of the palace, stands motionless, illuminated by artificial light and acclaimed by court officials and the people. Pseudo-Kodinos builds up suspense in his description. He describes the setting, the performers, their clothing, the props and, finally, the performance. Like a radio or television commentator he fills in time, while the emperor and his sons are changing their clothes on the platform, behind closed curtains, and taking up their positions. We can almost hear him whispering his commentary on the items of imperial clothing and their symbolic significance, ${ }^{86}$ as we wait for the curtains to part, revealing the emperor from the knees up and the emperor's sons from the chest up. ${ }^{87}$

I would suggest that if the Blachernai palace, as it emerges from the Treatise, seems pitifully small, if ceremonial space in the midfourteenth century seems terribly limited, this has more to do with the nature of the Treatise than the physical reality.

Indeed, that there is more to fourteenth-century ceremonial and the space in which it was conducted than the Treatise shows is indicated by Pseudo-Kodinos' mention only in passing of the twice daily receptions of title-holders before the emperor, ${ }^{88}$ and his omission of many ceremonies which, there can be no doubt, did take place in his time: imperial births, baptisms, weddings, funerals, and receptions of ambassadors. He does not give an account of any of the above directly, yet he describes aspects of some of these ceremonies, giving us reason to believe that the ceremonies did take place. For example, he provides the protocol for the reception of a foreign imperial bride-to-be in Constantinople, relating in passing the provisions for the suppliers of the drinks and for the entertainers. ${ }^{89}$ However, the protocol for a wedding is not given. Likewise, the anonymous author of the Treatise devotes a section to the attire of an emperor who is in mourning ${ }^{90}$ and elsewhere in the work he discusses the different arrangements for an emperor in

${ }^{85}$ Ed. Verpeaux, 195.24-204.23.

${ }^{86}$ Ed. Verpeaux, 200.14-202.14.

87 Ed. Verpeaux, 203.7-11.

88 Ed. Verpeaux, 191.22-23; 212.15-17.

${ }^{89}$ Ed. Verpeaux, 286-287, here 287.22-29.

90 Ed. Verpeaux, 284-285. 
mourning during the Christmas and Easter celebrations. ${ }^{91}$ Yet, there is no protocol for an imperial funeral. Again, he relates the different ways in which the representatives of the Genoese and the Venetians are received before the emperor at Christmas and Easter and when they first arrive in the capital, ${ }^{92}$ but he gives no specific protocol for the receptions of foreign ambassadors. Finally, Pseudo-Kodinos discusses at length the reason for the suite of horses that accompanies the emperor when he rides out to receive petitions from his subjects. ${ }^{93}$ To explain the origin of the custom, he relates an incident in the reign of the emperor Theophilos (829-842).$^{94}$ Furthermore, he recounts the kinds of instruments that accompany the emperor's riding out, when they are played and why ${ }^{95}$ However, he relates all this information as an aside to his description of the functions of the protostrator, ${ }^{96}$ and not as one of the ceremonies. ${ }^{97}$

Thus, comparison with the Book of Ceremonies shows the Treatise to provide a more limited description of ceremony. But the differences in content are misleading. It has been argued here that there is much more to the ceremonial life of the court in the mid-fourteenth century than Pseudo-Kodinos includes in his Treatise. And, if the Treatise is thin because it does not include all ceremonies, the Book of Ceremonies is fat because it includes a great deal of material not in use at the time of its compilation. Here we come to another important difference in the two works: the Book of Ceremonies is antiquarian, while the Treatise presents living ceremony, protocols that reflect ceremonies that were being performed in the mid-fourteenth century. Examples are the Christmas and Epiphany prokypseis, described also by Gregoras, the coronation protocol, given also by Kantakouzenos in his account

\footnotetext{
${ }^{91}$ Ed. Verpeaux, 226.22-228.3.

${ }_{92}$ Ed. Verpeaux, 234.28-235.13; 235.14-237.5.

${ }_{93}$ Ed. Verpeaux, 168.28-169.2; 170.6-171.7; Macrides, “"The reason is not known.”, pp. 325-328.

${ }_{94}$ Ruth Macrides, 'The ritual of petition', in: D. Yatromanolakis and P. Roilos, Greek Ritual Poetics (Washington, D.C. 2004) pp. 356-370, here pp. 359-364. The Madrid Skylitzes illustrates the emperor Theophilos' ride to the Blachernai in the course of which he was stopped by petitioners: Vasiliki Tsamakda, The Illustrated Chronicle of Ioannes Skylitzes in Madrid (Leiden 2002) fig. 95 (fol. 43 r).

${ }_{95}$ Ed. Verpeaux, 173.1-15.

${ }^{96}$ Ed. Verpeaux, 168.1, $28 \mathrm{ff}$.

${ }^{97}$ It could be the case that the author-compiler and his contemporaries did not consider the emperor's 'riding out' to hear petitions a ceremony as such. It did, however, have ritual elements such as its repetitive nature, the suite of horses in train, the fanfare that accompanied the emperor. See notes 93-95 above.
} 
of Andronikos III's coronation, the acclamation of the emperor by the Genoese ships, described by Gregoras, and the wearing of white for mourning, known also from Kantakouzenos and Gregoras. ${ }^{98}$ Therefore, the differences in size and content of the two texts have more to do with the different purposes and approaches of the compiler-authors than with a reduction in ceremonies.

Finally, the ceremonial of the late Byzantine court is also said to be isolated from the city, taking place in seclusion in the fortresslike remains of a palace. ${ }^{99}$ The Treatise, however, gives evidence for the emperor's attendance at the holy day celebrations in a number of churches throughout the city, the same number as in the time of the Book of Ceremonies. ${ }^{100}$ The emperor would have travelled to those churches on horseback and thus could have been seen by people lining the processional route, even if that route is not described by PseudoKodinos. Furthermore, the emperor's kaballikeuma or 'riding out' to receive petitions, brought emperor and inhabitants of the city into contact. ${ }^{101}$ Another point of contact was at the prokypsis ceremony in the courtyard of the palace. If the kathisma, that held the emperor and projected onto the Hippodrome, formed the interface between palace and Hippodrome in former times, the prokypsis in the courtyard of the Blachernai ${ }^{102}$ performed the same function in the later Byzantine period. Twice a year, at Christmas and Epiphany, the people of the city saw the emperor on an elevated platform, illuminated by artificial light and acclaimed with accompanying trumpets and other instruments. ${ }^{103}$

In the four hundred years separating the Book of Ceremonies from the Treatise of Pseudo-Kodinos, Byzantine ceremonial practice underwent many changes. Some change was brought about by external factors-

98 Prokypseis: Gregoras II, 617.23-618.5; coronation: Kantakouzenos I, 196.17204.3; acclamation of ships: Gregoras I, 134.15-18; white: Kantakouzenos II, 167.6-8; Gregoras II, 612.5-9.

99 Magdalino, 'Court and Capital in Byzantium', in this volume, pp. 141-143.

100 Magdalino, 'Pseudo-Kodinos' Constantinople', p. 1.

101 See above, p. 233.

102 Ed. Verpeaux, 197.1-204.7.

${ }^{103}$ Gregoras, II, 616.16-617.9 makes several references to the crowds of people, in addition to the army, gathered at the Christmas prokypsis of John V in 1341. He compares the mass of people to rivers that converged. See, in particular, II, 616.21, 24; 617, $6,8,9$. For the origins of the prokypsis ceremony which has parallels with the appearance of the emperor in the kathisma box at the Hippodrome, see G. Dagron, 'Trônes

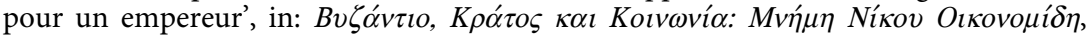
A. Avramea, A. Laiou and E. Chrysos, eds. (Athens 2003) pp. 179-203, here at pp. 184-185. 
the impoverishment of the state and the difficult political conditions. ${ }^{104}$ But everything we see in the Treatise cannot be explained by the latter. Imperial ceremonies are 'subject to the relentless process of historical change'. ${ }^{105}$ Even as the Book of Ceremonies was being compiled 'the great public imperial occasions in the Hippodrome were beginning to give way to private ceremony in the imperial palace'. ${ }^{106}$ Furthermore, exactly at the time when the Book of Ceremonies was being compiled (963-969), Nikephoros II Phokas erected a fortified wall dividing the upper terraces of the palace from the lower inhabited section. ${ }^{107} \mathrm{He}$ thereby turned the palace into 'a kind of castle'. ${ }^{108}$ Thus, already in the tenth century, the Great Palace was being compared to a fortress, as has been the Blachernai palace of the fourteenth century, ${ }^{109}$ and already in the tenth century ceremonial was taking on a less public role which has been described as a 'retreat of government from the public scene'. ${ }^{110}$ The same has been said of Pseudo-Kodinos' ceremonial. One should not therefore assume that what one sees in the Treatise are the signs of decay and loss. What we see, rather, is a development that had its origins in the great days of empire.

${ }^{104}$ Pseudo-Kodinos (ed. Verpeaux, 237.29-238.4) seems to acknowledge change effected by a lack of resources when he states 'It was an old custom at this vesper service for the emperor to enter the holy sanctuary and to cense the holy altar table and to give the clerics a gift of 100 pounds of gold from the vestiarion. Now this does not take place.'

${ }^{105}$ Michael McCormick, 'Analyzing imperial ceremonies', Jahrbuch der Österreichischen Byzantinistik 35 (1985) pp. 1-20, here p. 2; Cameron, 'The construction of court ritual', 136.

106 Cameron, 'The construction of court ritual', p. 131, citing Michael McCormick, Eternal victory (Cambridge 1986).

${ }_{107}$ Cyril Mango, 'The palace of the Boukoleon', Cahiers archéologiques 45 (1997) pp. 41-50, here at pp. 42-45.

${ }^{108}$ Ioannes Skylitzes, Synopsis Historiarum, I. Thurn, ed. (Berlin; New York 1973) 275.77-87.

${ }^{109}$ See Magdalino 'Court and capital in Byzantium', above p. 139; Henry Maguire, 'Images of the court', in: The Glory of Byzantium, Helen C. Evans and William D. Wixom, eds. (New York 1996) pp. 183-191, here p. 183; S. Ćurčić, 'Late medieval fortified palaces in the Balkans: security and survival', Monument and Environment 6 (2000) pp. 11-41, here pp. 11-17.

${ }_{110}$ Cameron, 'The construction of court ritual', p. 131. 